DOI:10.30842/ielcp230690152537

С. Д. Клейнер
(Институт лингвистических исследований РАН, Санкт-Петербург)

БОДЛЕАНСКИЙ «МАНДЕВИЛЬ»: ВОПРОСЫ ПЕРЕВОДА ${ }^{1}$

В статье сравниваются две рукописи, которые содержат «бодлеанскую» версию «Путешествий сэра Джона де Мандевиля», с точки зрения переводческих и компиляторских приемов, которые были задействованы в ходе их создания.

Ключевые слова: Мандевиль, итинерарий, теория перевода, история перевода, е Museo, Rawlinson.

S. D. Kleiner

(Institute for Linguistic Studies, RAS, St. Petersburg)

\title{
Bodley version of Mandeville's Travels: problems of translation
}

The article compares the two extant manuscripts containing the socalled Bodley version of Mandeville's Travels. The focus is on the techniques used to create the translation and both compilations.

Keywords: Mandeville, itinerary, translation theory, translation history, e Museo, Rawlinson.

\section{1. История вопроса}

Исследование бодлеанских версий «Путешествий сэра Джона Мандевиля» началось со статьи Й. Фогельса (Vogels 1891: 46-52). Он говорит, что рукописи е Museo 116 и Rawlinson D.99, несомненно, являются переводами с некоей сокращенной латинской версии, которая, в свою очередь, безусловно была переведена с французского (в пользу этой версии говорит, в частности, передача топонимов типа Comagnie, a также сетует на то, что эти рукописи содержат крайне сокращенный и видоизмененный текст «Путешествий». Он предполагает, что базовым латинским текстом для этих версий являлся некий вариант латинской рукописи MS Royal 13 E. ix, вкратце сравнивает е Museo 116 с версией Egerton - и приходит к следующему заключению: Существует два независимых друг от друга перевода «Путешествий» на английский язык. Один сделан с латинского перевода французского оригинала, который возник в 1390-1400 гг., а другой - непосредственно с

${ }^{1}$ Работа выполнена при поддержке гранта РНФ № № 17-18-01624 
французского. Перевод, сделанный с латинской версии, немного старше. Он дошел до нас в двух вариантах: е Museo 116 и Rawlinson D.99.

В 1953-м году М. Леттс (Letts 1953: 416-418) в предисловии к изданию Rawlinson D.99 усомнился в том, что источником для бодлеанских версий действительно является MS Royal 13 E. ix - как и в том, что обе бодлеанские рукописи являются вариантами одного и того же перевода. Он сравнивает Rawlinson D.99 с версией Egerton и находит в них гораздо больше сходства, отмечая при этом, что составитель Rawlinson D.99 очень вольно обошелся с текстом и «оживил» его при помощи многочисленных сокращений и перевода косвенной речи в прямую.

И наконец в 1963-м году М.С. Сеймур (Seymour 1963) выпустил подробное исследование «бодлеанских версий» с изданием е Museo 116. Он возвращается к идее о том, что именно MS Royal 13 E. ix является источником этой сокращенной версии - и издает е Museo 116 параллельно латинскому тексту. На этом работа с этими текстами удивительным образом заканчивается: дальнейшая литература ограничивается упоминаниями этих рукописей в числе прочих версий и рассуждениями об их месте в общей картине «Мандевильского» канона.

Таким образом, литература, посвященная бодлеанским рукописям, фокусируется, в значительной части, на попытках построить стему и проследить происхождение этой версии и проанализировать ее отношения с другими английскими вариантами «Путешествий». На этом фоне разговор о композиционных и языковых особенностях самих текстов представляется как нельзя более интересным.

В целом, с трактовкой Сеймура сложно не согласиться. Такие общие ошибки, как M Latynys (f. 10r), R Latyns (f. 3v) = latinos «римские священники», $\mathrm{M}$ in diserd (f. 10v), R. in the desert (f. 4r) = lat. loco deserto «в пустыне», $M$ though the grete cols there is a contynuel frost that the water freseth (f. $30 \mathrm{v}$ ), $\mathrm{R}$ thoruz the gret cooled and contynuel frost, the water fresith (f. 20v) $=$ propter frigus nimium et continuum gelu aqua congelatur «из-за чрезвычайного и постоянного мороза вода замерзает льдом» и др. не позволяет видеть в бодлеанских рукописях два разных перевода. Одновременно с этим, сами рукописи имеют большое количество расхождений в плане лексики, грамматики и компоновки. Этот вопрос будет обсуждаться ниже, но уже здесь стоит отметить, что даже если это действительно два 
списка с одного перевода, это никоим образом не мешает исследованию двух очень разных ветвей трансмиссии рукописного текста: консервативной (представленной е Museo 116) и вариативной (Rawlinson D.99).

В этой статье дается краткий обзор приемов и методов, которые удалось вычленить при сопоставлении двух рукописей друг с другом и с оригиналом. Она делится на две основные части - вопросы трансмиссии, то есть того, как обращаются с текстом переписчики в разных версиях, - и вопросы перевода, то есть какие приемы и каким именно образом использует переводчик с латинского на английский язык.

\section{2. Вопросы трансмиссии}

Рукопись е Museo 116 является комбинацией двух рукописей, которые были созданы в XV веке и переплетены вместе не позже 1600 года (Seymour 1963: xvi). Текст «Путешествий» занимает листы 6-64, написан двумя разными руками (смена руки - на с. 57) и окружен трактатом Чосера об астролябии и трактатом о деревьях Godfridus super Palladium. Он был написан, судя по всему, в первой трети XV века (Seymour 1963: xx).

Рукопись Rawlinson D.99 содержит только текст «Путешествий» (листы 1-31) и множество пустых страниц. Переплетены вместе они были в XVIII веке (Seymour 1963: xvii). Текст написан одной рукой, почерком второй половины XV века.

Как именно создавались и распространялись обе бодлеанские рукописи, доподлинно неизвестно. Если приблизительные датировки верны, то получается, что между созданием латинской версии и манускрипта e Museo 116 прошло не так уж и много времени, тогда как Rawlinson D.99 успела разойтись с е Museo 116 диалектально: e Museo написана на восточноанглийском диалекте, a Rawlinson D.99 - на южном.

B целом, две рукописи представляют собой два очень разных подхода к трансмиссии литературного текста. Ниже в этой части статьи будут даны примеры того, как составитель Rawlinson D.99 обращался с источником - и предложены возможные варианты объяснений тому, почему он это сделал.

\section{А. Синонимия}

(1) $\mathrm{M}$ this eche king of Hongery is a ful mighty king (f. $7 \mathrm{r}$ ) R The king of Hungrye is a ful myzti lorde (f. 1r), лат. rex... potens; 
(2) M and thane shul come into Gres to the cete of Sti, and from then into the cete of Fynpap, and the the cete of Andropolyn (f. 7r); R And thenne shal they come into Grece into the citee of Stye, and from Stye into the citee of Fynpapest, and thenne to Andropolyn (f. 1v), лат. civitate, civitatem, civitatem;

(3) M ...there they etyn for the grete hete that is there in that cuntre. Not forthy, whanne onye stronge men comyn among hem, they settyn up [bordes] as they don in othere placys (f. 12v); R they ete her mete, because of ouere gret heete that is in that cuntree. Nouzt for thy whenne any straungers comen, they sette at bordes as other men doen in 610ther cuntrees (f. 5v) лат. terra, alibi;

(4) M Alisaundre the Conquerour $<\ldots>$ sente his letteris to hem $<\ldots>$ And they wretyn here letterys again in this manner (f. $39 \mathrm{v}$ ); R Alizaundre the conquerour $\langle\ldots\rangle$ sente his lettres vnto hem $<\ldots>$ And they wrote her ansuere azeen (f. 25v-26r), лат. —, litteras.

Как можно видеть по этой небольшой выборке, дело не сколько в том, что Rawlinson D.99 избегает повторов, сколько в том, что их предпочитает е Museo 116. В целом, количество повторов лексем в этой рукописи больше, вне зависимости от того, какая лексема в латинском оригинале. С другой стороны, к «оригинальности» именно этой латинской версии по отношению к английскому тексту следует относиться с осторожностью - возможно, переписчики вносили в нее свои синонимы.

Случаи таких замен сравнительно редки, но как правило, разные лексемы или пропуск лексемы будут содержаться именно в Rawlinson D.99.

\section{Б. Пояснения}

(1) M Ich a monk of that hous hath euermore a lampe brennende (f. $16 \mathrm{r}$ ); $\mathrm{R}$ euery monk of that abbey hath eueremore a lawmpe brennynge in the chirche (f. 11r), лат. lampade suam;

(2) M And if that yryn be cast therein, it wele fletyn aboue (f. $23 \mathrm{v}$ ); R Also gif that any iren be cast therinne, it fletith aboue the watir (f. $15 \mathrm{r}$ ), лат. cicius supra nataret;

(3) M And whan men cuttyn hem (f. 23v); R but whenne men cutteth hem on sondre (f. 16r), лат. quibus tamen incisis;

(4) M beryn it vp onto an hey hyl (f. 41v); R and bereth it vnto an hille that is vsid therefore (f. 27r); лат. ad unum montem vicinum;

(5) M come thedyr and kysse the dragoun (f. 10v); R come and kisse hir, whenne she were in the likenes of a dragoun (f. $4 \mathrm{v}$ ); лат. cum venerit $<\ldots>$ et eam osculatus fuerit; 
(6) M And they shewn also the brende brom that Moyses saw (f. 17r); $\mathrm{R}$ Also they shewe there the brent brome that Moyses saw3, but some men seyn that it shulde be thorn (f. 11r); лат. Et monstratur quoque ibidem rubus incombustus quem viderat Moyses in eodem loco.

(7) $\mathrm{M}$ throur this desert may non hors passe for ther is in the woye non stable ne non esement for hors ne watyr to drynke (f. 16v); R thoruz thes desertis bifore seide may noon hors passe ffor in that waye is noo stable ne esement, nor watir to drynke (ff. 10r-10v); лат. per ista deserta nullus equs transire posset, non enim inuenitur pabulum equorum nec aqua ad bibendum.

(8) M For it semyth as it were fantem and disseyuable thing to syghte (f. 36r); R for it semeth a disseyuable thing to sizte (f. 23v); лат. quod sic quasi fantasticum et deceptorium visus;

(9) M Among alle the meruaylis and ferlyes of his lond that I have sen thane is a gret se al of grauel withoutyn ony porcioun of watyr therin (f. $35 \mathrm{v}$ ); R Amonges alle the wondres that I saw3, ther is a gret see of gravel (f. 23v); лат. inter alia mirabilia huius terre est illud mare arenosum quod totum de arena est sine gutta aque.

В целом, обе рукописи то добавляют, то убирают пояснения. Однако если сравнить с латинской версией, становится видна четкая тенденция: Rawlinson D.99 добавляет свой текст к латинскому и сокращает латинский, тогда как е Museo 116 остается верна латинскому тексту.

Так, в примере (1) в оригинале нет ни слова о том, что лампада эта горит в церкви. Нет ничего про церковь и в е Museo 116, однако составитель Rawlinson D.99 счел нужным это добавить. То же самое видим и в (2), (3) - и особенно (4), (5) и (6), где добавлены целые фразы и даже поправки, полностью отсутствующие и в латинском варианте, и в е Museo 116. С другой стороны, примеры (7), (8) и (9) показывают, что когда что-то опущено в Rawlinson D.99 по сравнению с е Museo 116, как правило, в латинском оригинале такая или похожая формулировка содержится.

Стоит полагать, что именно эти различия привели Летца к мысли, будто две бодлеанские рукописи являются результатами усилий независимых переводчиков: эти то вставленные, то опущенные уточнения в Rawlinson D.99 наводят на мысль, что создатель этой версии имел дело с несколько другим оригиналом - ведь в целом оба перевода довольно близко следуют за латинским текстом. Отчасти эту мысль подкрепляет следующий пункт. 


\section{В. Перестановка абзацев}

Если сравнивать две рукописи построчно, разница в порядке следования фрагментов получается весьма заметной. Так, в е Museo 116 рассказ о Константинополе, который начинается на f. 8r, как и в латинской версии, прерывается общим описанием Греции. B Rawlinson D.99 непосредственно после упоминания Константинополя вставлено описание императорского дворца, которое в е Museo 116 появляется лишь в конце следующей страницы. Таким образом, отрывок про Константинополь оказывается логичным и связным.

В части, где подробно рассказывается о Коране, (M ff. 25v27r; R ff. 17r-18r) порядок абзацев очень сильно изменен. В е Museo 116 он таков: Коран и Мухаммед - сарацинский рай вера в воплощение через Деву Марию - эпизод с Гавриилом - рассказ про роды под пальмой - Судный день - сара-цинские пророки - Рамадан - Евангелие - о евреях - Вознесение Христа - заключение о сродстве вер. На следующем листе можно встретить описание веры в Троицу. B Rawlinson D.99: Коран и Мухаммед - эпизод с Гавриилом - сарацинские пророки - Рамадан - Вознесение Христа - заключение о сродстве вер - сарацинский рай - рассказ про роды под пальмой - Евангелие - о евреях - о Троице. О вере в воплощение через Деву Марию можно узнать лишь на следующем листе. B Rawlinson D.99 параграфы начиная с «сарацинского рая» объединены в раздел De libro Alforayne et de doctrina eius - и действительно, эта компановка представляется более логичной: сперва читатель узнает про общие представления и обычаи, а затем ему рассказывают о конкретных постулатах Корана.

B e Museo 116 на листе f. 13r начинается рассказ про Вавилон и его правителя. То же самое видим и в Rawlinson D.99 на листе f. 6v. Начало почти идентичное, но после фразы And he wolde haue maryed me with a gret pryncis douztir, zif I wolde haue forsake my lawe; but I wolde nozt, for thenne muste me haue forsake my cristendome, but God it forbade в рукописи Rawlinson D.99 появляется подробнейший диалог от первого лица о христианских обычаях, который занимает целую страницу, после чего текст возвращается к And also this ilke Sawdon is lorde of v. rewmes that he hath wonne and proprid hem vnto him be his conquest (f. 7r) - то есть, к следующему абзацу е Museo 116. Этот диалог присутствует и в е Museo 116 - но намного дальше по тексту, на ff. 28r-29r. Здесь снова видно, как 
составитель Rawlinson D.99 перекомпоновывает текст, группируя отрывки схожей географии и тематики, чтобы создать более ясное повествование.

Rawlinson D.99 переставляет местами истории про Диндею (Нинидею) и вечно поющих дев, значительно сокращая рассказ про поющих дев (M ff. 47r-48r). Это, вероятно, вызвано тем, что рассказ про поющих дев под конец возвращает читателя в Диндею - и гораздо логичнее начать с него, а потом уже перейти к Диндее.

\section{Г. Добавление абзацев}

Между частями рассказа Rawlinson D.99 регулярно появляются отсутствующие в е Museo связки вида «А теперь я расскажу о...», что облегчает переходы от темы к теме.

На листе f. 16r в е Museo 116 заканчивается рассказ о Вавилоне и начинается рассказ о Палестине. B Rawlinson D.99 в этом же месте (f. 10r) вставлен рассказ о том, что в Аравии живет птица феникс.

K рассказу об обитателях Аравии (M f. 18v, R f. 12r) Rawlinson D.99 добавляет абзац о том, что не бывает лучших бойцов, чем эти люди, отсутствующий в е Museo и латинской версии.

\section{Д. Пропуск абзацев}

В конце рассказа о сарацинской вере е Museo 116 содержит абзац, призывающий доверять рассказчику, так как он видел всё собственными глазами и врать не будет (f. 28r). B Rawlinson D.99 этот абзац опущен.

Rawlinson D.99 также заметно сокращает рассказ о владениях пресвитера Иоанна, убирая подробное описание его дворца (M f. 36b), восхваление Бога после Опасной Долины (M f. 37b), абзац с объяснением странного обычая отдавать жену в первую брачную ночь другому мужчине (M f. 38v).

Rawlinson D.99 сокращает описание катанских обычаев (M f. $45 \mathrm{v})$ и быстрее переходит к ритуалу погребения катанского хана.

\section{Е. Анализ и заключение}

Bсе эти перестановки, добавления и пропуски, а также серьезнейшие текстологические расхождения, которые начинаются после рассказа про Иерусалим, вызывают серьезные подозрения в том, что перевод всё-таки действительно делался 
независимо и с разных версий. Но в такой трактовке не очень ясно, что делать с одинаковыми ошибками, которых в рукописях достаточно много и которые свойственны обеим рукописям.

Одним из решений проблемы было бы отнесение расхождений на уровень сокращенных латинских версий: возможно, их было больше одной, и переводы делались с разных версий? К сожалению, ответ на этот вопрос лежит в плоскости подробнейшего исследования латинских рукописей. Пока у нас нет двух вероятных кандидатов в латинские источники для бодлеанских версий, говорить о различии переводческих методов представляется затруднительным. Можно лишь строить догадки о том, как происходила трансмиссия сокращенной, а затем и бодлеанской версии «Путешествий».

В целом в перекомпановке рукописи нет ничего удивительного и необычного. Однако сравните фразы из начала и конца бодлеанских рукописей.

$R$ (f 30v) Ther is a rewme that is callid Nunydia, and the king theroff is callid Calamak, and is a gret lorde, and he hath vnder him liiij. iles. And [of] eueryche of thoo ilis is a crowned king, and alle they arn vnder him. And in thes iles arn men of dyuers shappis, as ze shal hire aftirwarde.

M ( $\mathrm{f} 47 \mathrm{r}$ ) There is a reume that is called Dyndeia, a riche lond and a plenteous. The king is called Calamak, a gret lord and myghti. He hath vnder him liiii. ylis that aryn meche and longe, and of eche of tho ylis is a coronyd king, and alle are thei obeysaunt to King Calamak. In tho ylis aryn men of dyuers condicionys, as ye shul here afterward.

$\mathrm{R}$ (f. 1r) For thy that many men desireth and coveytith to hire of the holy londe and of the londes of byzonde the see, that is to seye, be esten, in dyuers parties of the worlde; I, Iohn Maundevile, knyt, zif I vnworthi be, and born and norisshid in the rewme of Engelonde, out of the toun of Seint Albones; I passid on a daye into the see, on the daye of seint Mighel the archaungel, in the zeer of our lorde Iesu Crist a m.ccc. xxij.

$M$ (f. 6v) Forthy that manye men desyryn to heryn of dyuers londis and of the Holy Lond and of the Lond of Beheste and of othere dyuerse reumys beyond the see in dyuerse parties of the world, I, Iohn Mandeville, knight, thow I be unworthi, born and norisched in the reume of Ingeland of the toun of Seynt Albonis passed the see vpon a day of Seynt Michel the Archaungel in the yer of oure lort Uesu Crist m.ccc and xxii. 
Перекомпановка ли это - или всё-таки разные переводы? Пока нет альтернативной латинской версии, вопрос остается нерешаемым. Впрочем, в любом случае кто-то когда-то перекомпановал текст так, чтобы он выглядел логично. Возможно, это был переписчик Rawlinson D.99 - а возможно даже и переводчик этой рукописи.

В любом случае, перед нами - две традиции бытования литературного текста. В традиции, которая представлена е Museo 116, текст близок к оригиналу и старается повторять его структуру, добавляя как можно меньше лишнего и отнимая как можно меньше текста. Вторая традиция, представленная Rawlinson D.99, решает задачу удержания зрительского интереса: совсем скучные места вроде описания дворца опускаются; предложения-связки в начале каждой отдельной истории облегчают зрительское восприятие; вставки интересных фактов о фениксе и о том, что аравийцы - лучшие в мире воины поддерживают интерес. Перестановка абзацев местами позволяет сохранить логику текста: абзацы, рассказывающие об одной локации, компонуются вместе, чтобы не путать читателя, а сложное повествование о сарацинской вере и обычаях структурируется, разделяясь на интуитивно понятные категории. В текст также добавляются пояснения там, где их может не хватить, и убирается лишнее там, где, на взгляд составителя рукописи, и так всё понятно. Результат - более краткая, но гораздо более «интенсивная» и логичная версия «Путешествий».

Переписчик, таким образом, выступает своего рода соавтором текста, выбирая, какие места и в каком порядке лучше подавать своему читателю, чтобы текст оставался увлекательным и информативным. В такой ситуации наличие «канонического» текста представлялось, разумеется, совершенно немыслимым - да и попросту ненужным. Разумеется, приход печатного станка кардинально изменил эту ситуацию.

\section{3. Вопросы перевода}

Так как вопросы, могущие затрагивать два разных перевода, невозможно решить, не обнаружив альтернативный латинский оригинал, остается основываться на более «лояльном» к вероятному латинскому источнику манускрипте е Museo 116. Впрочем, здесь можно вычленить и проанализировать переводческие приемы и техники. 


\section{А. Лексические приемы}

Транскрипция, транслитерация и калькирование.

Здесь, разумеется, речь пойдет об именах и топонимах. При этом очевидно, что расхождения в именах собственных между рукописями огромны: M Noscelawe, R Ruslawe; M Fynpap, R ffynpapest; M Mincafla, R Myncalpha и т. д. Это, разумеется, вызвано в первую очередь трансмиссией и накоплением ошибок в незнакомых именах и топонимах.

Калькирование в первую очередь представлено титулами и терминами. L Soldanus - M Soudon, R Sawdon; L adamantes $\mathrm{M}$ adamaundes, $\mathrm{R}$ adomaundis; $\mathrm{L}$ cadeberios $-\mathrm{M}$ gadiberis, $\mathrm{R}$ gadybers и т. д.

\section{Лексико-семантические замены}

Конкретизация

L Volo autem aliquid loqui - M Now wole I tellyn and declaryn and spekyn; L cadunt sub rotis illius currus - $M$ fallyn under whelis of waynis and of cartis; inquit pater - M sayde the Emperour; L veniunt volantes desuper, videlicet vultures, aquile, et alie huiusmodi que carnibus viuunt - $\mathrm{M}$ that is for to say, botoris, eagles, rauenys, and puttokys, and othere foulis that leuyn by carayn.

\section{Генерализация}

$L$ et omni hora diei mutator odor fontis et sapor $-M$ and manye tyme of the day the watir chaungith; $\mathrm{L}$ bellatores $-\mathrm{M}$ men.

\section{Модуляция}

L Uxores consanguineas suas, exceptis matribus - $\mathrm{M}$ wives here sisteris by the faderis syde, but not bi the moderis side; L hoc ipsi $\mathrm{M}$ alle hese frendys; $\mathrm{L}$ nec oculos leuare - $\mathrm{M}$ loke aboute hem, $\mathrm{R}$ loke doun to the erthe.

Это - лишь некоторые примеры из огромного количества лексических замен, которые можно встретить в е Museo 116. Они говорят о том, что переводчик активно осмыслял текст и старался сделать его как минимум понятным. Однако главные достижения текста - в грамматических преобразованиях.

\section{Грамматические преобразования}

В качестве иллюстрации были выбраны три примера.

(1) L Ad predictum ydolum veniunt peregrini de longinquis ita comuniter sicut faciunt Christiani ad sanctum Iacobum in Galacia, et hoc com magna deuotione; plures enim qui peregre veniunt de longinquis 
versus ydolum ipsum, propter deuotionem quam habent semper ad terram respiciunt itinerando, nolentes respicere in circuitu nec oculos leuare ne forte aliquid videant quod posset impedire suam deuotionem.

M To that ymage, that is here principal mamet, comyn pilgrymys out of fer countries as comounly as Cristene men come to Seynt Iamys, and that with gret deuocioun and euermore lokende doun to the erthe, not willynge to loke aboute hem for thei shulde don nothing that shulde lette here deuocioun.

$\mathrm{R}$ And to that mawmette comen manye pilgrymes of ferre cuntrees, as cristen men doen vnto Seint Iames. And as they goo they loke doun to the erthe, and they wole nozt loke by cause of her devocioun.

E Museo 116, нетипично для себя, подробно поясняет, какой идол имеется в виду. Оба перевода расширяют de longinquis как fer countries. E Museo 116 объединяет две латинские части предложения, чтобы не повторять plures enim qui peregre veniunt de longinquis versus ydolum ipsum. Rawlinson D.99 идет еще дальше: ставит точку и начинает новое предложение, сокращая его еще почти в два раза.

В целом заметно, что даже близко и местами дословно следуя оригиналу, E Museo 116 не калькирует все латинские конструкции. respicere et oculos leuare переводится как to loke aboute hem, а предложение значительно сокращено. Rawlinson D.99 идиоматичнее и свободнее: they loke doun to the erthe существенная переинтерпретация, которая при этом создает гораздо более понятный и яркий образ.

(2) L Noueris quod quando socii mei et ego fuimus in valle ipsa introeunted, fluctuauimus cogitatione an ulterius procedere vellemus et committere not diuine protectioni. Aliqui vero nostril consenserunt transire, aliqui vero contradicebant.

M Mynn felawis and I, whan we wer in that vale and herdyn speke thereof, some of vs cestyn in our herte to puttyn vs in the mercy of God al holly and passyn thour that Vale Perilyous, and some forsokyn and seydyn they woldyn not puttyn hem into that peril.

R But my felawes and I caste in our hertis to putte vs fully to the mercy of lesu Grist and to passe that Vale Perilous. And some seiden that they wolde nouzt putte hemself in that pereille.

Здесь тоже видно, что идиомы переводятся при помощи идиом: fluctuauimus cogitatione передается как cestyn in our herte и caste in our hertis. Непонятно, действительно ли латинский 
оригинал был похож на источник второй части этого фрагмента; если это так, то перед нами - яркий пример пояснительного перевода, когда смысл латинской фразы раскрывается при помощи совершенно других слов и конструкций - своего рода, внутреннего комментария.

(3) L Tempore quondam Alexandri magni misit eisdem idem rex ad gented istam ad explorandum patriam, quia voluit eam sibi subicere sicut et ceteras.

$\mathrm{M}$ Whan Alisaundre the Conquerour regnede and conquered al the world, in that tyme he com by that yle and sente his letteris to hem that dwelledyn therinne, and seide he wolde dispolyen here lond but if they woldyn ben vndyr his subieccioun and hym vndyrloute as othere londis and contreis dedyn.

$\mathrm{R}$ Whenne Alizaundre the conquerour regned and conquered al the worlde, in that tyme he come be an ile, and sente his lettres vnto hem and seide, that he wolde dispoile her londe, but zif they wolde be vnder his subieccioun, as othir cuntrees were.

Здесь очевидно, что латинская версия не могла послужить источником ни для одного из английских переводов; при этом английские переводы почти полностью идентичны.

\section{Анализ и заключение}

Попытка анализировать перевод бодлеанских рукописей неизбежно сталкивается с проблемой отсутствия однозначного оригинала. Неизвестно, был ли источник один - или несколько; если Rawlinson D.99 является результатом сильной переработки, то ее большая краткость и идиоматичность - плод самой обыкновенной текстовой редактуры; но даже относительно e Museo 116 однозначные выводы представляются невозможными, потому что сопоставление перевода с оригиналом не представляется возможным: MS Royal 13 E. іх очень похожа на оригинал, но очевидно им не является.

Впрочем, перевод интересен слабым процентом калькирования. Предложения сокращаются и делятся; в тексте появляются пояснения; идиомы передаются при помощи идиом; английский перевод не следует за латинской грамматикой, а подчиняется законам английского языка. Всё это говорит о том, что представление об английском языке как о литературном было уже довольно крепким: переводы на «нелитературный» язык не отличаются такой степенью свободы, потому что латынь «сильнее» и важнее, а язык перевода представляется лишь средством 
для облегчения понимания, чего в случае бодлеанских рукописей явно не наблюдается.

\section{4. Итог}

Как видно из сопоставления рукописей, ранненовоанглийский воспринимался как язык, на котором можно создавать и распространять литературные произведения. Учитывая, что «отцом» этого представления был, судя по всему, Джефри Чосер, умерший в 1400-м году - примерно тогда же, когда создавался бодлеанский перевод - можно заключить, что процесс этот шел крайне быстро и, очевидно, стал результатом накопленных после норманского завоевания языковых характеристик и контекстов. Идиоматичность, свободные переложения, современные переводческие приемы - всё это немыслимо, например, для готской Библии, да и для любых переводов на языки, которые только-только обретают статус литературных.

При этом представление о том, что художественное произведение существует только в одном «правильном» варианте, очевидно, еще не было сформированным - да и не могло быть сформированным в силу специфики рукописной традиции по сравнению с печатной. Бодлеанские рукописи - одни из последних носителей старой традиции, которую, как и традицию переводов через язык-посредник - латынь - вместо новых литературных языков, вскоре ожидало полное забвение.

\section{Литература}

Letts, M. (ed.). 1953: Mandeville's Travels. Texts and Translations. Vol. 2. London.

Seymour, M. C. (ed.). 1963: The Bodley version on Mandeville's Travels. From Bodleian MS E Musaeo 116 with parallel extracts from the Latin text of British Museum MS. Royal 13 E. ix. Oxford.

Vogels, J. 1891: Handschriftliche Untersuchungen für die englische Version Mandeville's. Crefeld. 